\title{
Study on Utility of Different Multipurpose Trees as Black Pepper Standards in Lateritic Soil of Uttara Kannada District of Karnataka, India
}

\author{
L. Venkatesh ${ }^{1 *}$, M. J. Manju ${ }^{1}$, K. L. Kavya ${ }^{1}$ and K. P. Singh ${ }^{2}$ \\ ${ }^{1}$ ICAR-Krishi Vigyan Kendra (UAS, Dharwad), Sirsi, Uttara Kannada, Karnataka (India) \\ ${ }^{2}$ College of Horticulture and Research Station, Jagdalpur, Bastar \\ *Corresponding author
}

\begin{abstract}
A B S T R A C T

\begin{tabular}{|c|}
\hline Keywords \\
\hline $\begin{array}{l}\text { Black Pepper } \\
\text { Standards, } \\
\text { Multipurpose Trees }\end{array}$ \\
\hline Article Info \\
\hline $\begin{array}{l}\text { Accepted: } \\
\text { 16 November } 2020 \\
\text { Available Online: } \\
10 \text { December } 2020\end{array}$ \\
\hline
\end{tabular}

The experiment was carried out in the a farmer's field at Antravalli village, Kumta taluk of Uttar Kannada district. They were planted of different 4 year old multipurpose trees, which are planted as supporting trees for black pepper variety -Panniyur (2 year old) with $2 \times 2 \mathrm{~m}$. spacing. Experimental results revealed that, 90 Days After Implementation: The significantly higher height was recorded in black pepper with Aquilaria malaccensis (1.46 $\mathrm{m})$ followed by Grevilia robusta $(1.37 \mathrm{~m})$, Swetania mahagony $(1.28 \mathrm{~m})$, and Pajanelia longifolia $(1.25 \mathrm{~m})$ respectively. The least height was recorded for vine which was trained for Gliricidia sepium $(1.08 \mathrm{~m})$. However, Percentage increase in height of vine was maximum increase in height of black pepper was observed with Grewilia robusta (13.86 $\%)$ followed by Aquilaria malaccensis (8.90\%), Pajanelia longifolia (8.8\%), and Gliricidia sepium (4.63\%). The least per cent increase was observed with Sweitania mahagony $(3.90 \%)$. the Light transmission ratio (\%) was maximum with Grevilia robusta (51.66\%) followed by Aquilaria malaccensis (39.02\%), Pajanelia longifolia $(34.39 \%)$ and least for Swetania mahagony $(19.31 \%)$.
\end{abstract}

\section{Introduction}

Agroforestry systems and practices that effectively integrate trees with agricultural crops assume greater importance particularly in the sensitive soils of the tropics (Kumar and Nair, 2004). The main attributes contributing to the sustainability of these systems are biophysical advantages such as efficient nutrient cycling offered by multispecies composition, conservation of bio-cultural diversity, product diversification as well as market values of products and services, and social and cultural values including the opportunity for gender equality in managing the systems. Black pepper (Piper nigrum L.) the 'king of spice', cultivation in lateritic soil of Uttara Kannada district (Karnataka) is a prominent agro forestry system. It is one of the important spice commodities of commerce and trade in India since pre-historic period.

Where, the tree component forms an integral in the home gardens and farm lands usually on part of the production system. As pepper 
grown under the shade of supporting trees, it is traditionally grown under few support trees as coconut and areca nut (conventional species).Good numbers of MPTs (non conventional species) are also suitable for block cultivation of pepper. As many as 27 species were found to be serving as good pepper live standards (Salam et al., 1991).

In terms of total area, India ranks first and as for as productivity $(315 \mathrm{~kg} / \mathrm{ha})$ is concerned India is in the last position (Madan, 2000).So, with respect to improve the yield, fast establishment, low crown spread, amenability to lopping and physical suitability for trailing pepper are some of the potential factors that favor higher pepper yield. The total surface area available for the vine to cling to the support trees and the distribution of sunlight under them are also important factors for yield of black pepper vines (Korikanthimah et al., 1988).

An ideal living support for pepper should be straight growing and should have a tap root system that does not compete with black pepper for water, nutrients and solar radiation; slender, but strong trunk with a rough surface; ability to withstand regular pruning and pollarding, and have economic value after the life span of the crop (Sivaraman et al., 1999).

However, block planting of black pepper is mostly confined to very few preferred species such as areca nut and hardly with silver oak. The humid, high rainfall condition of Uttara Kannada (Karnataka) suits to the growth of large number of fast growing MPTS which has been, by practice, found suitable as pepper support trees. However, the performance of many such MPTS as support trees has not been tested especially when planted in dense blocks

The functional role of the support trees in pepper based intensive production systems has been little studied beyond their physical suitability for trailing pepper. Site enrichment by nutrient turnover through litter fall and lopped biomass form the characteristic feature of such systems (George and Kumar, 1998). Tree roots often serve as efficient nutrient pumps by way of drawing nourishment from deeper soil and thereby enrich the top soil.

The safety net mechanisms by tree roots might exert considerable control over nutrient leaching from these systems (Allen et al., 2004).Near neutral soil pH, high organic matter content and high base saturation with $\mathrm{Ca}$ and $\mathrm{Mg}$ were found to influence nutrient uptake and productivity of black pepper (Mathew et al., (1995). However, the cumulative effect of the tree components on the overall system productivity might vary with the tree species in tree pepper based production systems. The present study was carried out to evaluate the utility of different plantation growing MPTs as black pepper standards.

\section{Materials and Methods}

\section{Study area}

The study was carried out in the Central Western Ghats, a village called Antravalli $\left(14.4711^{\circ} \mathrm{N}\right.$ latitude, $74.4599^{\circ} \mathrm{E}$ longitude and 20m above mean sea level), near Kumta, Uttar Kannada district of Karnataka (Fig. 1). The study area has a tropical climate with well defined rainy season between June and November. Isolated showers may also occur during December and May.

The annual average rainfall is about 3667 $\mathrm{mm}$. The average temperature is $27^{\circ} \mathrm{C}$. The soil type of the site is lateritic, which is derived from metamorphic rocks, which are rich in iron and manganese. This soil is quite acidic and with the low $\mathrm{pH}$. 


\section{About experiment plot}

The plot is owned by a farmer namely, Mr.Narayana Dattatreya Hegde, at Nadigadde post, Antravalli, Kumta Taluk, Karwar district, Karnataka.

The size of experimental plot is 19 ha. The plot consists of different multipurpose trees, which are planted as supporting trees for blackpepper. The year of multipurpose trees planted was June 2016.So; the age of different MPTs is almost 2 year old. The year of black pepper planted was April 2018.The variety planted over there is Panniyur.

The spacing followed over there is $2 \mathrm{x}$ $2 \mathrm{~m}$. And the planting design followed over there is randomized block design (RBD).The few management practices followed in the plot by farmer are pruning of tree(done at the month of May of the year), providing of soil amendments (like FYM and burnt paddy husk) and well managed for drainage.

Black pepper grows successfully between $20^{\circ}$ North to $20^{\circ}$ South of equator and from sea level up to $1500 \mathrm{~m}$ above MSL. It is a plant of humid tropics, requiring $2000-3000 \mathrm{~mm}$ of rainfall, tropical temperature and high relative humidity with little variation in day length throughout the year. Black pepper does not tolerate excessive heat and dryness. Variation in day length throughout the year. Black pepper does not tolerate excessive heat and dryness.

\section{Rainfall and relative humidity}

Total rainfall and its distribution play an important role in black pepper cultivation and productivity. An annual rainfall of $2000 \mathrm{~mm}$ with uniform distribution is ideal. Rainfall of $70 \mathrm{~mm}$ received in 20 days during May - June is sufficient for triggering off flushing and flowering processes in the plant, but once the process is set off there should be continuous shower until fruit ripening. Any dry spell even for a few days, within this critical period of 16 weeks (flowering to fruit ripening) will result in low yield (Pillay et al., 1988). In black pepper growing areas of Indonesia and Malaysia (Sarawak), the average annual rainfall is $2300 \mathrm{~mm}$ (Wahid and Sitepu, 1987) and $3950 \mathrm{~mm}$, respectively (De Waard, 1969). In India, black pepper growing areas receive $1500 \mathrm{~mm}$ to more than $4000 \mathrm{~mm}$ rainfall. Rainfall after stress induces profuse flowering (Pillay et al., 1988). Growth of fruit bearing lateral shoots (plagiotrophs) and photosynthetic rate are maximum during peak monsoon in India (June - July) (Mathai, 1983). A relative humidity of $60-95 \%$ is optimum at various stages of growth.

\section{Temperature}

The crop tolerates temperature between 10 $40^{\circ} \mathrm{C}$. The ideal temperature is $23-32^{\circ} \mathrm{C}$ with an average of $28^{\circ} \mathrm{C}$. Optimum soil temperature for root growth is $26-28^{\circ} \mathrm{C}$ (De Waard, 1969; Wahid and Sitepu, 1987).

\section{Light / Solar radiation}

Black pepper is a day neutral plant. Vijayakumar et al., (1984) found that black pepper vines exposed to direct solar radiation developed physiological disorders even under favorable soil moisture conditions. Black pepper vines kept' under shade (7\% incident light) remained green and healthy whereas those exposed to sunlight turned yellow and developed necrotic patches during summer (Vijayakumar and Mammen, 1990). Fifty per cent shade boosted the growth of black pepper cuttings in the nursery (Senanayake and Kirthisinghe, 1983). Illumination above 50,000 lux, decreased carbon fixation in a few varieties of black pepper (Mathai, 1983). The top portion of the black pepper vine receives more sunlight which declines gradually 
downwards and this is attributed to mutual shading of the vine (Ramadasan, 1987; Mathai and Chandy, 1988).

Shade regulation of live standards is an important cultural practice during rainy cloudy weather to allow sufficient light for crop growth; if not, the yield will be reduced to $50 \%$ or more (Ramadasan, 1987). Use of reflect ants is common to reduce stress during summer. Spraying lime over the leaf surface enhanced the chlorophyll content (Vijayakumar et al.,. 1984); however, it reduced the yield compared to china clay (Vijayakumar and Mammen, 1990).

\section{Soil}

Soils suitable for black pepper at different production centers have been reviewed earlier (De Waard, 1969; Purseglove et al., 1981; Wahid and Sitepu, 1987; Sadanandan, 1994). Black pepper grows well on soils ranging from heavy clay to light sandy days rich in humus with friable nature, well drained, but still with ample water holding capacity. Soils with near neutral $\mathrm{pH}$, high organic $\mathrm{f}$ matter and high base. saturation with $\mathrm{Ca}$ and $\mathrm{Mg}$ enhanced the productivity 1 (Mathew et al., 1995). Soil for black pepper cultivation requires a composition of $0.26 \% \mathrm{~N}, 0.25 \%$ $\mathrm{P}_{2} \mathrm{O} 0.41 \% \mathrm{~K}, \mathrm{O}, 0.18 \% \mathrm{MgO}$ and $0.5 \% \mathrm{CaO}$ (Wahid and Sitepu 1987). Ward ani and Zaubin (1984) reported that black pepper varieties differ in their growth with respect to soil $\mathrm{pH}$ and soils with $\mathrm{pH}$ above 7.5 inhibit growth.

However, Sangakkara (1989) reported that growth of the variety Panniyur 1 was the highest at $\mathrm{pH} 7.8$ and 8.1. Water logged soils and diseased soils are not suitable for black pepper cultivation (Nambiar et al., 1965; De Waard 1979). Well drained loamy soils rich in humus nourish the crop well and the best crop could be obtained in virgin forest soil.

\section{Description of MPTs selected for the study}

Multipurpose trees are defined as all woody perennials that are purposefully grown to provide more than one significant contribution to the production and/or service functions of a land-use system. They are so classified according to the attributes of the plant species as well as to the plant's functional role in the agro forestry technology under consideration (after Burley and von Carlowitz, 1984). Any woody perennial species can be 'multipurpose' in one situation and 'single purpose' in another

\section{Experimental Results and Discussion}

\section{Growth attributes of black pepper}

\section{Number of leaves}

The experiment was initiated in the month of July and observations were recorded at every 30 days of interval.

\section{Days after implementation}

The highest leaves were recorded with pepper vine which was trained for Aquilaria malaccensis (43) followed by Pajanelia longifolia (42) and Swetania mahagony (29) respectively. The least No. of leaves was recorded with Grewilia robusta (table-2). Whereas at 90 DAI: The highest leaves were recorded for pepper vine which was trained for Aquilaria malaccensis (47) followed by Pajanelia longifolia(45), Gliricidia sepium (25) and Swetania mahagony (25) respectively. The least leaves were recorded for vine which was trained for Grewilia robusta (table-2) and the Percentage change in number of leaves: Highest per centage change in number of leaves was observed in Grewilia robusta (10.0) followed by Aquilaria malaccensis (8.51), Pajanelia longifolia (6.66) and Gliricidia sepium (4.16). The least percentage change was observed for 
Swetania mahagony (16) (Table-2 and Fig. 2).

\section{Height of vine (m)}

30 Days after implementation: The highest height was observed for pepper vine which was trained for Aquilaria malaccensis $(1.33 \mathrm{~m})$ followed by Swetania mahagony y $(1.23 \mathrm{~m})$, Grewilia robusta $(1.18 \mathrm{~m})$ and Pajanelia longifolia $(1.14 \mathrm{~m})$ respectively. The least height was recorded for vine which was trained for Gliricidia sepium $(1.03 \mathrm{~m})$ the height of pepper vine at 90 DAI: The highest height was observed for pepper vine which was trained for Aquilaria malaccensis $(1.46 \mathrm{~m})$ followed by Grewilia robusta $(1.37 \mathrm{~m})$, Swetania mahagony $(1.28 \mathrm{~m})$ and Pajanelia longifolia $(1.25 \mathrm{~m})$ respectively. The least height was recorded for vine which was trained for Gliricidia sepium $(1.08 \mathrm{~m})$. however, the Percentage increase in height of vine was maximum percentage increase in height of vine was observed for Grewilia robusta (13.86) followed by Aquilaria malaccensis (8.90), Pajanelia longifolia (8.8) and Gliricidia sepium (4.63). The least percentage increase was observed with Swetania mahagony (3.90) (Table-2 and Fig. 3).

\section{Growth attributes of multipurpose tree species}

\section{Height of tree (m)}

\section{Days after implementation}

The experiment was initiated in the month of July and observations were recorded at every 30 days of interval. There was a significant difference in height of MPTs. The MPTs, Gliricidia sepium recorded the maximum height $(4.68 \mathrm{~m})$ followed by Grevillea robusta $(4.18 \mathrm{~m})$ and Aquilaria malaccensis $(4.38 \mathrm{~m})$. The least height was observed with Pajanelia longifolia $(2.58 \mathrm{~m})$ whereas after 90 DAI: At there was a significant difference among different MPTs with respect to their height. The highest height was recorded with Gliricidia sepium $(5.15 \mathrm{~m})$, followed by Aquilaria malaccensis $(4.85 \mathrm{~m})$ and Grevillea robusta $(4.73 \mathrm{~m})$. The least height was observed with Pajanelia longifolia $(2.85 \mathrm{~m})$. However, Percentage increase in height of MPTs: Good percentage increase in height of MPTs was observed in Grewilia robusta (11.62) followed by Aquilaria malaccensis (9.70), Pajanelia longifolia (9.47), and Swetania mahagony (9.34 Gliricidia sepium (9.12) (Table-3 Fig.4) recorded least percent increase in height

\section{Girth of tree (m)}

30 Days after implementation:, Pajanelia longifolia recorded the maximum girth $(0.24 \mathrm{~m})$ followed by Swetania mahagony $(0.22 \mathrm{~m})$ and Grevillea robusta $(0.21 \mathrm{~m})$. The least girth was observed with Gliricidia sepium $(0.16 \mathrm{~m})$ at 90 DAI: The tree, Pajanelia longifolia was recorded the maximum girth $(0.26 \mathrm{~m})$ followed by Grevillea robusta $(0.23 \mathrm{~m})$ and Swetania mahagony $(0.23 \mathrm{~m})$. The least girth was observed for Gliricidia sepium $(0.17 \mathrm{~m})$. whereas Percentage increase in girth of MPTs: Good percentage increase with respect to height of MPTs was observed with Grewilia robusta (8.70) followed by Pajanelia longifolia (7.70), Aquilaria malaccensis (5.26), and Gliricidia sepium (9.12).The least percentage increase was observed for Swetania mahagony (4.34) (Table-3, Fig. 5).

\section{Light transmission ratio (\%)}

\section{Days after implementation}

There was a significant difference with respect to LTR (\%) by different MPTs. The highest LTR was recorded with Aquilaria 
malaccensis (64.62\%) followed by Gliricidia sepium (61.85\%) and Gliricidia sepium $(60.44 \%)$.The lowest LTR was recorded for Pajanelia longifolia (12.35\%) at 60 DAI: There was a significant difference with respect to LTR (\%) by different MPTs after 60 days. The highest LTR was recorded for Grevillea robusta(48.71\%) followed by, Pajanelia longifolia (29.14\%) Aquilaria malaccensis (13.15\%).The lowest LTR was recorded for Gliricidia sepium $(6.57 \%)$. However, at 90 DAI. There was a significant difference with respect to LTR (\%) by different MPTs after 90 days. The highest LTR was recorded with Grevillia robusta (51.66\%) followed by Aquilaria malaccensis (39.02\%) and Pajanelia longifolia (34.39). The lowest LTR was recorded for Swetania mahagony (19.31\%) So, the highest mean LTR(\%) after 90 days implementation was Grewilia robusta (51.66\%) followed by Aquilaria malaccensis (39.02\%), Pajanelia longifolia (34.39\%). The least mean LTR was observed for Swetania mahagony (19.31\%) (Table-4 and Fig 6).

\section{Results and Discussion}

The black pepper vine requires a support for its establishment. Both living and non-living supports (standards) are used to establish black pepper. An ideal living support should be straight growing and should have a tap root system that does not compete with black pepper for water, nutrients, and solar radiation; slender, but strong trunk with a rough surface; ability to withstand regular pruning and pollarding, and have economic value after the life span of the crop (Sivaraman et al., 1999). Use of ideal support trees plays a significant role in growth and yield of black pepper. A variety of trees are used as living standards (Wardell 1991; Salam et al., 1991).

Table.1 List of MPTs selected for the study

\begin{tabular}{|c|l|c|c|}
\hline Sl.No. & Botonical names & Family & Common Names \\
\hline 1 & Grevillea robusta & Proteaceae & Silver oak \\
\hline 2 & Swietenia mahagoni & Meliaceae & Mahagony \\
\hline 3 & Aquilaria malaccensis & Thymelaeaceae & Agar wood \\
\hline 4 & Pajanelia longifolia & Bignoniaceae & Pajanelia \\
\hline 5 & Gliricidia sepium & Fabaceae & Gliricidia \\
\hline
\end{tabular}

Table. 2 Growth attributes of black pepper with different MPTS

\begin{tabular}{|c|c|c|c|c|c|c|c|c|}
\hline \multirow[t]{3}{*}{ Treatments/MPTs } & \multicolumn{4}{|c|}{ Number of leaves } & \multicolumn{4}{|c|}{ Height of vine (m) } \\
\hline & \multicolumn{8}{|c|}{ Days after implementation } \\
\hline & 30 & 60 & 90 & $\%$ change & 30 & 60 & 90 & $\%$ increase \\
\hline T1-Grewilia robusta (Silver oak) & 18 & 18 & 20 & 10.00 & 1.18 & 1.33 & 1.37 & 13.86 \\
\hline T2-Swetania mahagony (Mahagony) & 29 & 24 & 25 & -16 & 1.23 & 1.18 & 1.28 & 3.90 \\
\hline T3-Aquilaria malaccensis (Agar wood) & 43 & 47 & 47 & 8.51 & 1.33 & 1.45 & 1.46 & 8.90 \\
\hline T4-Pajanelia longifolia (Pajanelia) & 42 & 40 & 45 & 6.66 & 1.14 & 1.20 & 1.25 & 8.8 \\
\hline $\begin{array}{l}\text { T5-Gliricidia sepium } \\
\text { (Gliricidia) }\end{array}$ & 23 & 24 & 25 & 4.16 & 1.03 & 1.04 & 1.08 & 4.63 \\
\hline MEAN & 31 & 30.6 & 32.4 & 4.32 & 1.18 & 1.24 & 1.29 & 8.53 \\
\hline
\end{tabular}

*DAI-Days after Implementation 
Table.3 Growth Attributes of Mpts

\begin{tabular}{|l|c|c|c|c|c|c|c|c|}
\hline \multirow{2}{*}{ Treatments/MPTs } & \multicolumn{7}{|c|}{ Height of tree(m) } \\
\cline { 2 - 9 } & \multicolumn{9}{|c|}{ Days after implementation } \\
\hline & $\mathbf{3 0}$ & $\mathbf{6 0}$ & $\mathbf{9 0}$ & $\mathbf{\%}$ Increase & $\mathbf{3 0}$ & $\mathbf{6 0}$ & $\mathbf{9 0}$ & \% Increase \\
\hline $\begin{array}{l}\text { T1-Grevillea robusta } \\
\text { (Silver oak) }\end{array}$ & 4.18 & 4.65 & 4.73 & 11.62 & 0.21 & 0.21 & 0.23 & 8.70 \\
\hline $\begin{array}{l}\text { T2-Swetania mahagony } \\
\text { (Mahagony) }\end{array}$ & 3.88 & 4.13 & 4.38 & 9.34 & 0.22 & 0.22 & 0.23 & 4.34 \\
\hline $\begin{array}{l}\text { T3-Aquilaria malaccensis } \\
\text { (Agar wood) }\end{array}$ & 4.38 & 4.40 & 4.85 & 9.70 & 0.18 & 0.19 & 0.19 & 5.26 \\
\hline $\begin{array}{l}\text { T4-Pajanelia longifolia } \\
\text { (Pajanelia) }\end{array}$ & 2.58 & 2.67 & 2.85 & 9.47 & 0.24 & 0.26 & 0.26 & 7.70 \\
\hline $\begin{array}{l}\text { T5-Gliricidia sepium } \\
\text { (Gliricidia) }\end{array}$ & 4.68 & 4.93 & 5.15 & 9.12 & 0.16 & 0.17 & 0.17 & 5.88 \\
\hline MEAN & 3.94 & 4.16 & 4.39 & 10.25 & 0.20 & 0.21 & 0.21 & 6.38 \\
\hline
\end{tabular}

*DAI-Days after Implementation

Table.4 Light transmission ratio (\%) under different MPTs

\begin{tabular}{|l|c|c|c|c|}
\hline \multirow{2}{*}{$\begin{array}{l}\text { Mreatments/ } \\
\text { MPTs }\end{array}$} & \multicolumn{4}{|c|}{ Light Transmission ratio (\%) } \\
\cline { 2 - 5 } & \multicolumn{4}{|c|}{ Days after implementation } \\
\hline $\begin{array}{l}\text { T1-Grewilia } \\
\text { (Silver oak) }\end{array}$ & $\mathbf{3 0}$ & $\mathbf{6 0}$ & $\mathbf{9 0}$ & Mean \\
\hline $\begin{array}{l}\text { T2-Swetania mahagony } \\
\text { (Mahagony) }\end{array}$ & 64.44 & 6.71 & 51.34 & 19.31 \\
\hline $\begin{array}{l}\text { T3-Aquilaria malaccensis } \\
\text { (Agar wood) }\end{array}$ & 60.43 & 13.15 & 43.47 & 39.02 \\
\hline $\begin{array}{l}\text { T4-Pajanelia longifolia } \\
\text { (Pajanelia) }\end{array}$ & 12.35 & 29.14 & 61.70 & 34.39 \\
\hline $\begin{array}{l}\text { T5-Gliricidia sepium } \\
\text { (Gliricidia) }\end{array}$ & 61.85 & 6.51 & 12.33 & 26.89 \\
\hline
\end{tabular}

*DAI-Days after Implementation

Table.5 Light Transmission ratio (\%) under different pepper standards

\begin{tabular}{|l|c|c|c|c|}
\hline \multirow{2}{*}{ Treatments/ MPTs } & \multicolumn{4}{|c|}{ Light intensity ratio (\%) } \\
\cline { 2 - 5 } & \multicolumn{4}{|c|}{ Days After Implementation } \\
\hline $\begin{array}{l}\text { T1-Grewilia } \\
\text { (Silver oak) }\end{array}$ & $\mathbf{3 0}$ & $\mathbf{6 0}$ & $\mathbf{9 0}$ & Mean \\
\hline $\begin{array}{l}\text { T2-Swetania mahagony } \\
\text { (Mahagony) }\end{array}$ & 64.44 & 48.71 & 51.34 & 19.31 \\
\hline $\begin{array}{l}\text { T3-Aquilaria malaccensis } \\
\text { (Agar wood) }\end{array}$ & 60.44 & 6.57 & 14.93 & 39.02 \\
\hline $\begin{array}{l}\text { T4-Pajanelia longifolia } \\
\text { (Pajanelia) }\end{array}$ & 12.35 & 13.15 & 43.47 & 34.39 \\
\hline $\begin{array}{l}\text { T5-Gliricidia sepium } \\
\text { (Gliricidia) }\end{array}$ & 61.85 & 29.14 & 61.70 & 26.89 \\
\hline
\end{tabular}

*DAI-Days after Implementation 
Fig.1
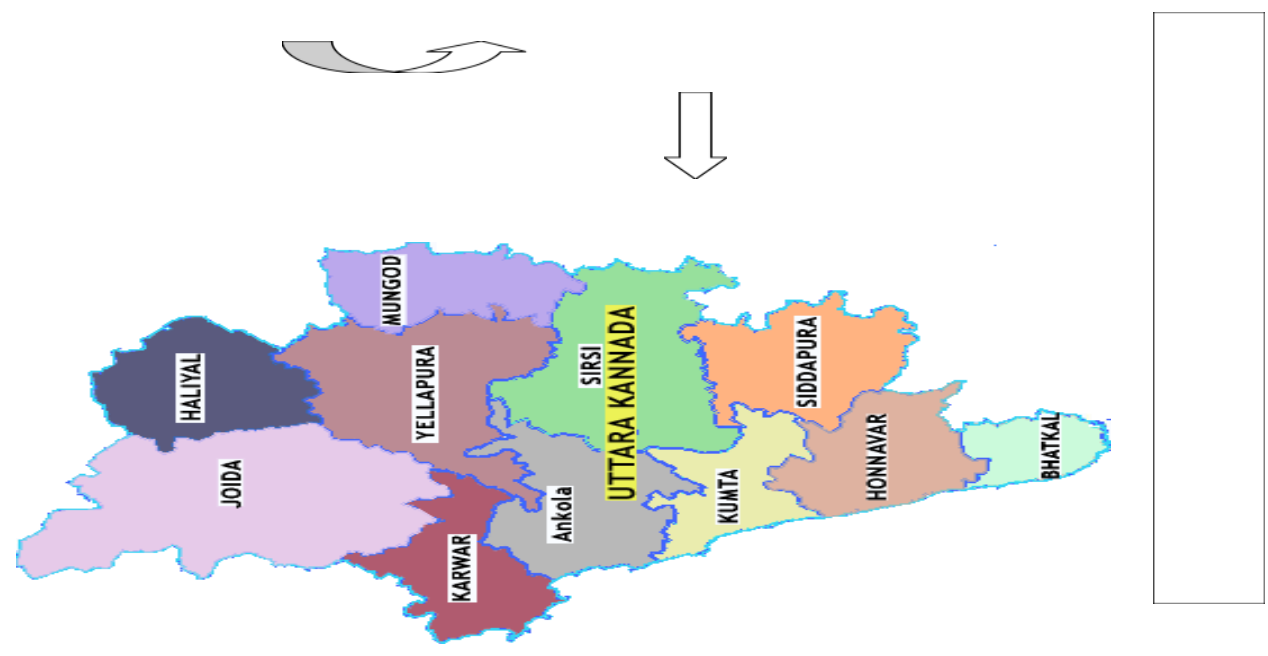

Fig.2 Mean LTR (\%) FOR 90 DAYS

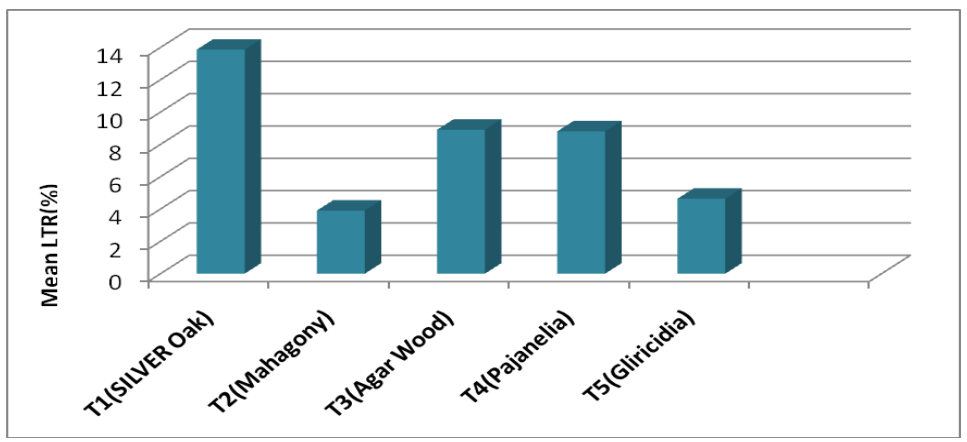

Fig.3 Percentage increase in height of vine

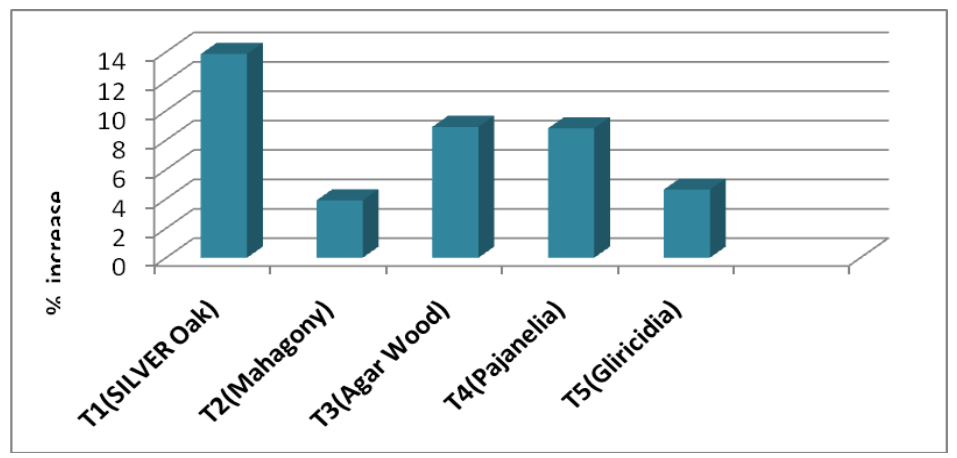


Fig.4 Percentage increase in height of trees

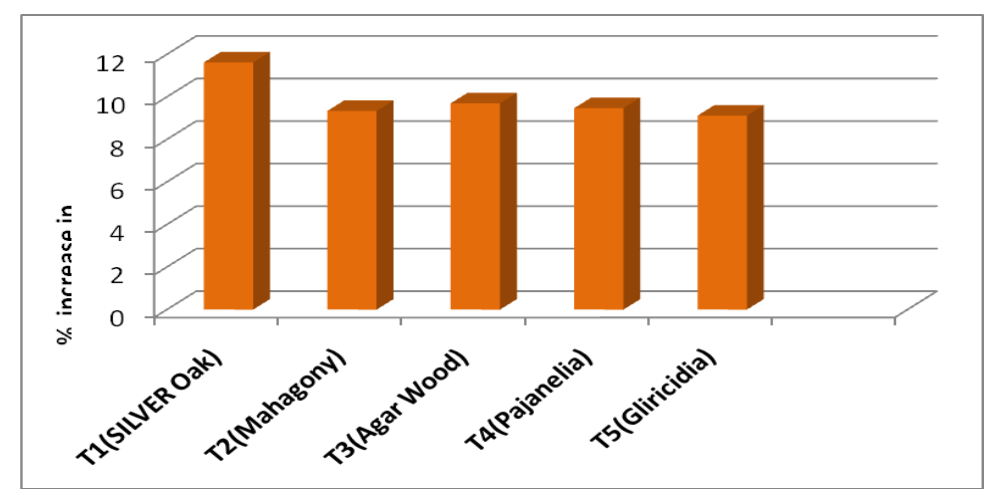

Fig.5 Percentage increase in girth of trees

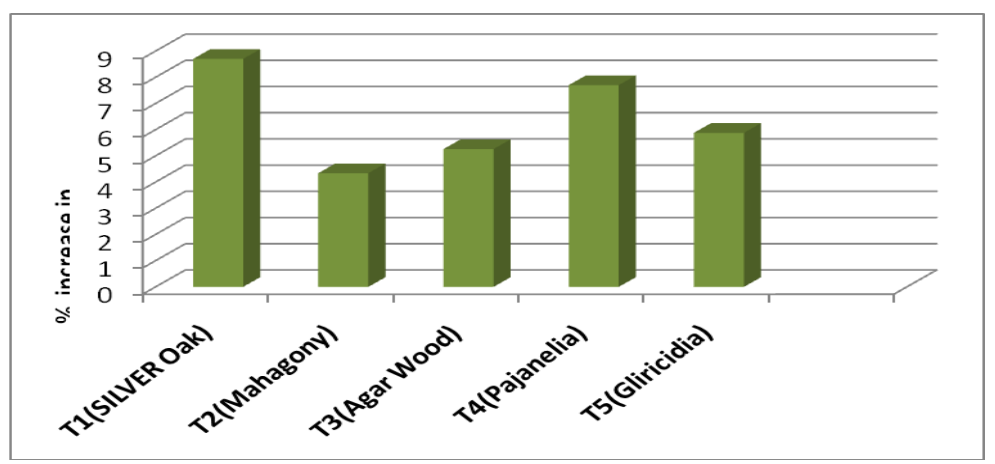

Fig.6 Mean LTR (\%) FOR 90 DAYS

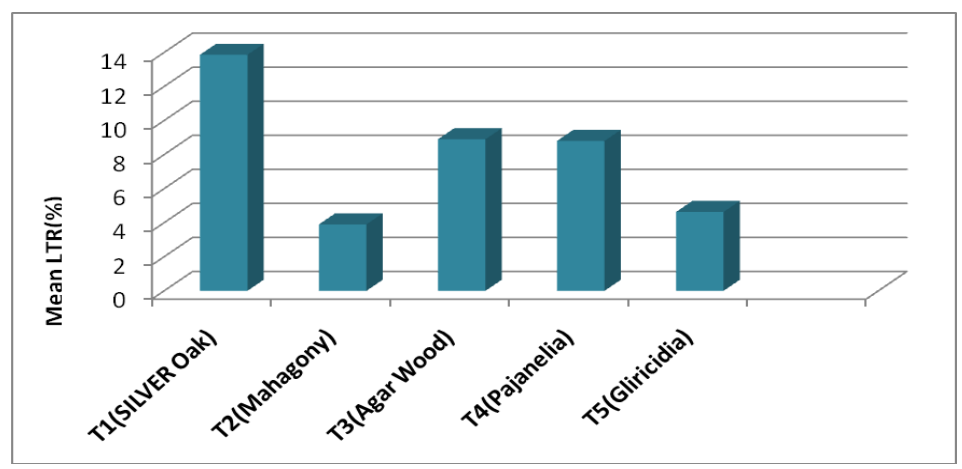

The study shows that, the growth of black pepper depends on different parameters of support trees like, girth (Korikanthimath etal.(1988),Light transmission ratio (Mathai et al.,1988),nature of bark (Sivaraman et al., 1999) and its height.

The good percentage increase, with respect to growth of black pepper (height and number of leaves) were recorded for the vines which were trained with the standard, Grevillia robusta followed by Aquilaria malaccensis, Pajanelia longifolia and Gliricidia sepium. Least growth was observed for the vine, which was trained for Swetania mahagony. The possible explanation would be poor physical suitability for pepper growth. The smooth bark probably deters the pepper vine from making the 
effective anchorage with the tree, the low mean light transmission ratio which is responsible for low vegetative and leaf growth and least radial growth (girth) responsible for reduced total surface area available for the vine to cling.

\section{References}

Kunhamu, T.K., Kumar, B.M. and Jamaludheen, V., 2012. Utility of multipurpose trees as black pepper (Piper nigrum L.) Standards in the humid tropics of Kerala. Indian J Agrofor, 14(1), pp.1722.

Krishnamurthy, K.S., Parthasarathy, V.A., Saji, K.V. and Krishnamoorthy, B., 2010. Ideotype concept in black pepper (Piper nigrum L.). Journal of Spices and Aromatic Crops, 19(1\&2), pp.01-13.

Kato, O.R. and Albuquerque, F.C., 1980. Relationship between support size and black pepper productivity. Pesquisa em Andamento. Altamira, (4).

Mathai, C.K., 1983. Growth and yield analysis in black pepper varieties (Piper nigrum L.) under different light conditions. PhO Thesis, University of Agricultural Sciences, Bangalore.

Mathai, C.K. and Sastry, K.S.K., 1988. Productivity of black pepper vines (Piper nigrum L.) as influenced by the light availability during pre flowering stage. Comparative physiology and ecology.

Mathew, T., Kumar, B.M., Babu, K.V.S. and Umamaheswaran, K., 1996. Evaluation of some live standards for black pepper. Journal of Plantation Crops, 24(2), pp.86-91.

Mathew, P.G., Wahid, P.A. and Sreekandan Nair, G., 1995. Soil fertility and nutrient requirement in relation to productivity in black pepper (Piper nigrum L.). Journal of Plantation Crops, 23, pp.109-115.

Parthasarathy, V.A., Sasikumar, B., Nair, R.R. and George, K.J., 2007. Black pepper: botany and horticulture. Horticultural Reviews-Westport then New York-, 33, p.173.

Sivaraman, K., Kandiannan, K., Peter, K.V. and Thankamani, C.K., 1999. Agronomy of black pepper (Piper nigrum L.)-a review. Journal of Spices and Aromatic Crops, 8(1), pp.01-18.

Thangaselvabal, T., Justin, C.G.L. and Leelamathi, M., 2008. Black pepper (Piper nigrum 1.) 'the king of spices'-a review. Agric. Rev, 29(2), pp.89-98.

Wong, T.H. and Paulus, A.D., 1993. Evaluation of live supports for black pepper.

\section{How to cite this article:}

Venkatesh, L., M. J. Manju, K. L. Kavya and Singh, K. P. 2020. Study on Utility of Different Multipurpose Trees as Black Pepper Standards in Lateritic Soil of Uttara Kannada District of Karnataka, India. Int.J.Curr.Microbiol.App.Sci. 9(12): 2214-2223.

doi: https://doi.org/10.20546/ijcmas.2020.912.261 